
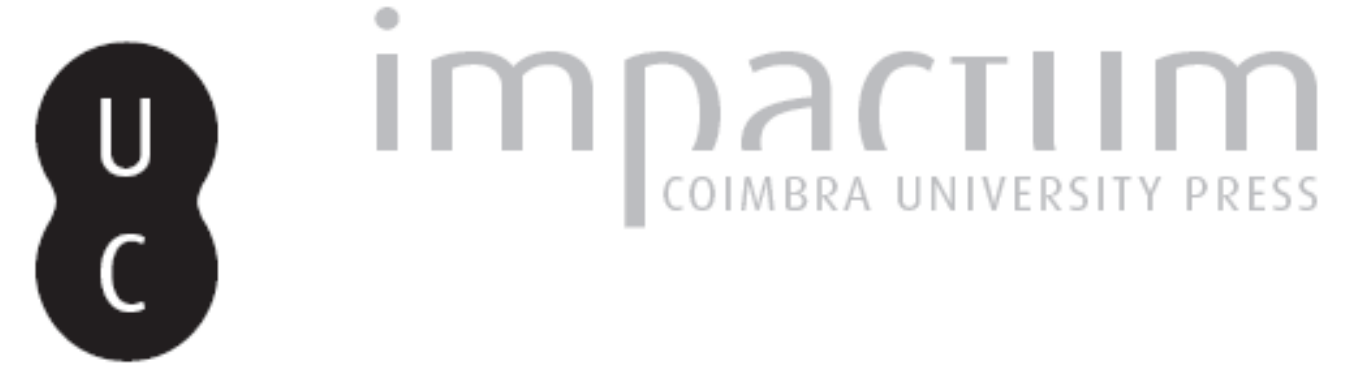

\title{
Epitafios-denuncia del homicidio de dos mujeres romanas
}
Autor(es): $\quad$ González Herrero, Marta
Publicado por: Faculdade de Letras da Universidade de Coimbra/Imprensa da Universidade de Coimbra

URL persistente:

URI:http://hdl.handle.net/10316.2/41877

DOI:

DOI:https://doi.org/10.14195/1647-8657_55_14

Accessed : $\quad$ 26-Apr-2023 14:14:48

A navegação consulta e descarregamento dos títulos inseridos nas Bibliotecas Digitais UC Digitalis, UC Pombalina e UC Impactum, pressupõem a aceitação plena e sem reservas dos Termos e Condições de Uso destas Bibliotecas Digitais, disponíveis em https://digitalis.uc.pt/pt-pt/termos.

Conforme exposto nos referidos Termos e Condições de Uso, o descarregamento de títulos de acesso restrito requer uma licença válida de autorização devendo o utilizador aceder ao(s) documento(s) a partir de um endereço de IP da instituição detentora da supramencionada licença.

Ao utilizador é apenas permitido o descarregamento para uso pessoal, pelo que o emprego do(s) título(s) descarregado(s) para outro fim, designadamente comercial, carece de autorização do respetivo autor ou editor da obra.

Na medida em que todas as obras da UC Digitalis se encontram protegidas pelo Código do Direito de Autor e Direitos Conexos e demais legislação aplicável, toda a cópia, parcial ou total, deste documento, nos casos em que é legalmente admitida, deverá conter ou fazer-se acompanhar por este aviso.
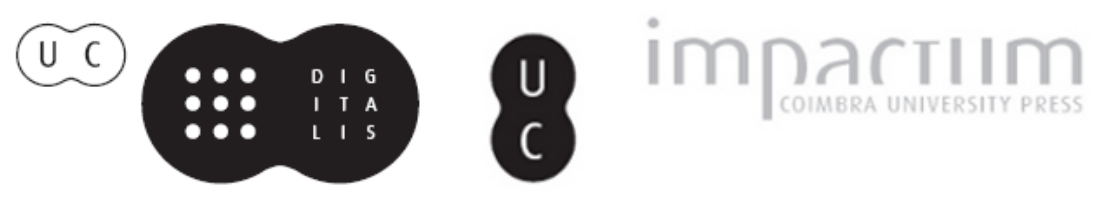
CONIMBRIGA

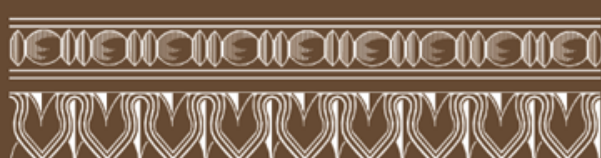

INSTITUTO DE ARQUEOLOGIA

VOLUME LV • 2016

FACULDADE DE LETRAS
UNIVERSIDADE DE COIMBRA 
Marta González Herrero

Universidad de Oviedo

martaher@uniovi.es

EPITAFIOS-DENUNCIA DEL HOMICIDIO

DE DOS MUJERES ROMANAS

EPITAPH AS INSTRUMENT OF ACCUSATION

AGAINST THE KILLER OF TWO ROMAN WOMEN

“Conimbriga” LV (2016) p. 269-287

https://doi.org/10.14195/1647-8657_55_14

RESUMEN: Se estudian dos epitafios que presentan una interesante particularidad: en ellos se acusa a quien ha dado muerte a la persona fallecida violenta y voluntariamente. En ambos casos, los dedicantes fueron los parientes masculinos de dos mujeres, Iulia Maiana y Prima Florentia, quienes perdieron la vida a manos de sus maridos en Lugdunum y Roma respectivamente.

Palabras Clave: epigrafía latina, venganza, violencia de género, Iulia Maiana, Prima Florentia.

ABSTRACT: The aim of this paper is to study two unusual epitaphs that contain an accusation against the person who killed the deceased. The dedicators were male relatives of the female victims, Iulia Maiana and Prima Florentia who were murdered by their husbands in Lugdunum and Rome.

Keywords: Latin Epigraphy, Gender Violence, Revenge, Iulia Maiana, Prima Florentia.

Conimbriga, 55 (2016) 269-287 
Página deixada propositadamente em branco 


\section{EPITAFIOS-DENUNCIA DEL HOMICIDIO DE DOS MUJERES ROMANAS ${ }^{1}$}

\section{Introducción}

Con todo epitafio se trata de perpetuar el recuerdo de la persona fallecida para que no muera del todo al seguir viva en la memoria de los demás. En la Antigüedad, la función comunicativa propia de la epigrafía condiciona la forma de transmitir este mensaje (DonATI y SusINI 1986 65-78), al estar el monumento funerario concebido para ser expuesto en un espacio público ante los ojos de todo aquel que se detiene a contemplarlo.

Consecuentemente la grabación de una inscripción funeraria es una oportunidad inmejorable para presentar una imagen ideal del difunto en un lugar representativo para él, pero también para exponer la de los familiares que cumplen con su deber hacia el ser querido.

Se estudian aquí dos epitafios excepcionales en el conjunto de la epigrafía latina recogida en el territorio del Imperio romano. Ambos presentan la interesante particularidad de que conmemoran a la persona fallecida, pero a la vez se acusa a quien le dio muerte voluntaria y violentamente. En ellos se aprecian ciertas similitudes que les hacen merecedores de un estudio particular: se denuncian crímenes en el seno de la familia y los dedicantes son los parientes masculinos de las víctimas.

${ }^{1}$ El presente trabajo se enmarca dentro del proyecto de I+D, "Marginación política, jurídica y religiosa de la mujer durante el Alto Imperio Romano (siglos I-III)", financiado por el Ministerio de Economía y Competitividad dentro del programa estatal de fomento de la investigación científica y técnica de excelencia (HAR2014-52725-P).

Conimbriga, 55 (2016) 269-287 


\section{El epitafio de Iulia Maiana (FIG. 1)}

El monumento funerario que recuerda la muerte de Iulia Maiana fue hallado en Lugdunum, capital de la Galia Lugdunense (CIL XIII, 2182; PAvÓn ToRrejón 2011 253-262). Se trata de un precioso cipo de piedra caliza descubierto en 1856 en el Jardín des dames de Saint-Michel (Saint-Irénée, Lyon). Hoy está depositado en el Musée gallo-romain de Lyon-Fourvière (sala $15, \mathrm{n}^{\circ} 326$ ).

El tipo de letra, el uso de un superlativo no habitual (crudelissi$m u s)$ y la dedicación bajo ascia ${ }^{2}$ - fueron grabadas dos afrontadas entre las siglas $D(i s) M($ anibus $)$ - permiten datar el monumento entre mediados del siglo II y las primeras décadas del siglo III.

D(is) M(anibus) / ET QVIETI AETERNAE / IVLIAE MAIANAE FEMI/NAE SANCTISSIMAE MANV / 5 MARITI CRVDELISSIM(i) INTER/FECT(ae) QVAE ANTE OBi $<$ I $>$ IT QVAM FATVM / DEDIT CVM QVO VIX(it) ANN(OS) XXVIII EX / QVO LIBER(OS) PROCREAV(it) DVOS PVERVM / ANN(OrUm) XVIIII PVELLAM ANNOR(um) XVIII / ${ }^{10}$ O FIDES O PIETAS IVL(ius) MAIOR FRA/TER SORORI DVLCISS(IMAE) ET [ING]ENVINIVS / IANVARIVS FIL(ius) EIVS P(onendum) [C(urauerunt) ET SV]B A(scia) D(edicauerunt)

Consagrado a los dioses Manes y al reposo eterno de Iulia Maia$n a$, mujer muy virtuosa muerta antes del momento señalado por el destino asesinada por la mano de un muy cruel marido. Vivió con él veintiocho años y tuvo de él dos hijos, un chico de dieciocho y una chica de diecinueve años. ¡Oh, Fidelidad sagrada! ¡Oh, Piedad! Iulius Maior para su muy querida hermana y el hijo de ésta Ingenuinius Ianuarius se preocuparon de poner(lo) y (lo) dedicaron bajo ascia.

La única dificultad interpretativa que la inscripción plantea es de-

${ }^{2}$ El significado que la representación del ascia tiene en los monumentos sepulcrales ha suscitado un debate historiográfico comentado pormenorizadamente por ENCARNAÇÃo (2008 399-403). La aportación del epigrafista portugués ha sido fundamental por haber llamado la atención sobre la palabra francesa asse (en flamenco essette), con la que se identifica un instrumento empleado por el barrilero para preparar los cajones de madera, muy similar al ascia que aparece en los túmulos romanos. Objeto de uso corriente, el ascia se fue convirtiendo en un símbolo protector del difunto, cuyo cuerpo o espíritu descansa bajo la madera moldeada.

Conimbriga, 55 (2016) 269-287 
terminar cuál es la función sintáctica del término crudelissim. Hay varias posibilidades:

a) se trata del adverbio de modo crudelissim(e) que expresa la crueldad con la que el marido de Iulia Maiana la mató (muy cruelmente).

b) es un adjetivo en grado superlativo que acompaña al sustantivo manus (por la crudelísima mano).

c) es un superlativo que califica a maritus (por la mano de un muy cruel marido).

Nótese cómo hay una intención clara de llamar la atención sobre la figura del marido cuando se elabora la imagen de la difunta: estuvo siempre junto a él (cum quo) y de él (ex quo) tuvo dos hijos. Por ello, se ha optado por que crudelissimus también se refiera a la persona para contraponer la crueldad del esposo (maritus crudelissimus) al virtuosismo de la difunta (femina sanctissima). Se logra un equilibrio epigráfico con el que también se potencia el rechazo hacia el homicida.

Iulia Maiana fue recordada como madre y abnegada esposa, una mujer que estuvo casada veintiocho años y dio dos hijos a un marido que acabó matándola. La difunta cumplió con el papel que la sociedad romana esperaba de una mujer por el hecho de serlo: que compartiera su vida con un único hombre (uniuira) y que procreara hijos legítimos, es decir, habidos dentro del matrimonio. ${ }^{3}$ Era lo deseable para toda femina santissima, como bien ilustran las palabras que Marcial dirige a la bretona Claudia Rufina (Epigramas XI, 53): "Gracias a los dioses que, fecunda, dio hijos a su virtuoso marido, y que, siendo aún joven, espera tener yernos y nueras. Quieran los dioses que se agrade con un solo marido iy goce siempre de la presencia de sus tres hijos!".

\footnotetext{
${ }^{3}$ Reproduciendo así honorables ciudadanos, a quienes sus madres debían transmitir el mos maiorum, CENERINI (2002 26-28). Es esta una forma completamente diferente de ejercer la ciudadanía a la de los hombres, MARTínez LóPEz (1999 143-162; Cid LóPEZ (2002 11-50; 2009 125-152). Igual que ellos engrandecen su dignitas participando en la gestión de la ciuitas, la mujer romana conquista su dignidad cuando atiende la llamada masculina para ser madre, momento en que se percibe que la personalidad femenina se encuentra en un estado cuasi divino, CASTRESANA (1993 15). Sobre el matrimonio romano la bibliografía es muy prolífica. Especialmente recomendable es el trabajo de Treggiari (1991) por la riqueza de fuentes jurídicas, literarias y epigráficas y el de Astolfi (2002) por las nuevas perspectivas que ofrece a la hora de abordar el estudio de esta institución.
}

Conimbriga, 55 (2016) 269-287 
El ara fue dedicada por dos personas: Iulius Maior, hermano de la difunta, y el hijo de ésta Ingenuinius Ianuarius. En el estudio que Pilar Pavón Torrejón (2011 254-255 nota 4) dedica a este documento, llama la atención sobre una inscripción votiva hallada en la Galia Bélgica (CIL XIII, 8789) en la que figura un homónimo del hijo de Iulia Maiana. Lo poco común de su nombre gentilicio lleva a la autora a no descartar que pueda tratarse de la misma persona, pero los indicios no son concluyentes.

Este Ingenuinius Ianuarius dedicó un altar pro salute de sus hijos en uno de los templos consagrados a la diosa Nehalennia en el mar del Norte, cerca de Domburg a algo más de seiscientos Kilómetros de Lugdunum. Atendiendo a la onomástica todo apunta a que el dedicante era originario de esta región, ya que es precisamente en la Galia Bélgica donde se concentran los escasos testimonios de su gentilicio, un nomen de tipo germánico formado a partir del patronímico Ingenuus. ${ }^{4}$

La condición de hijo y que su madre fuese enterrada en Lugdunum apuntan a que la familia de Iulia Maiana estaba establecida en esta ciudad, donde sin embargo no contamos con más testimonios de miembros de la gens Ingenuinia. Sí hay uno a trescientos Kilómetros de distancia, concretamente en Autessiodurum (Auxerre), donde Ingenuinia Aurelia y sus dos hijos dieron sepultura al cabeza de familia, un notable llamado Aurelius Demetrius (CIL XIII, 2924, p. 35; CAG 10 142). Estos dos epígrafes recogidos en la Galia Lugdunense revelan que miembros de la gens Ingenuinia emigraron a esta provincia desde la no muy lejana Galia Bélgica.

Podríamos pensar que el hijo de Iulia Maiana visitó el templo localizado en la tierra de origen de su familia paterna. Tal vez fueron razones de índole económica las que justifican su presencia en esta región puesto que Nehalennia es una divinidad marina protectora de los viajeros y de sus intereses (GrEen 1995 69), a la que se rindió culto en una zona de tránsito comercial entre Bretaña y las ciudades germanas. En contra de esta posibilidad está la constatación de que los cultores de la diosa que acudieron a sus templos eran originarios de ciudades próximas y en su onomástica hay un buen número de gentilicios de idéntica

${ }^{4}$ MóCsY y LóRINCZ (1999-2002 193). Los autores recogen cinco más: tres en la Galia Bélgica (CIL XIII, 7981, CIL XIII, 8424 y CIL XIII, 8789), uno en Italia (CIL V, 6839) y otro en la Lugdunense referenciado a continuación (CIL XIII, 2924).

Conimbriga, 55 (2016) 269-287 
formación que Ingenuinius (RAEPSAET-CHARLIER 2003292 nota 6): Terinius, Victorinius, Vitalinius, Iucundinius, Amminius, Auerinius, Carinius, Catullinius, Iustinius, Maximinius, Ottinius y Similinius

La datación del ara poco clarifica ya que fue grabada durante la primera mitad del siglo II (RÉvILLE 1873-75 18-20) y los templos consagrados a Nehalennia en la costa del mar del Norte estuvieron activos entre 150-250 (STUART y BogaERs 2001), precisamente cuando el hijo de Iulia Maiana dedicó el epitafio.

\section{El epitafio de Prima Florentia (FIG. 2)}

Las letras legibles en el epitafio de Prima Florentia fueron bastamente ejecutadas sobre una placa de mármol blanco adosada a la pared de una tumba cuyo contexto arqueológico permite datarla en el siglo II, sin más precisión (ThYLANDER $1952 \mathrm{nr}$. A 210 pl. LX: 2; Solin 1987 124 nr. 12; Helttula 2007 nr. 321). Hoy se encuentra depositado en el almacén de la necrópolis de Ostia, en el área de Isola Sacra a dos decenas de kilómetros al oeste de Roma.

RESTVTVS PISCINESIS / ET PRIMA RESTVTA PRIMAE / FLORENTIAE FILIAE CARISSIMAE / FECERVNT QVI AB ORFEV MARITV IN /5 TIBERI DECEPTA EST DECEMBER COGNATV $/ / \mathrm{s}^{5} /$ POSVIT Q(uae) vix(it) ANN(os) XVI

Restutus Picinesis y Prima Restuta (lo) hicieron para su muy querida hija Prima Florentia, quien fue arrojada al Tíber por su marido Orfeus. December, un pariente de sangre, (lo) puso. Vivió dieciséis años.

La familia presenta una curiosa onomástica. Heikki Solin (SoLIN 1987124 nr. 12) plantea la posibilidad de que Picinesis sea la origo o el oficio de Restutus, lo que significaría que el padre de la joven usaba un nombre personal único. Este era el caso tanto del marido de Prima Florentia como de December. En cuanto a Prima -que comparten madre e hija- el investigador finlandés considera que puede tratarse de un cognomen que funciona como nombre gentilicio. Sea como fuere, nos encontramos ante una familia residente en Roma en algún momento del

${ }^{5} \mathrm{La}$ letra $\mathrm{V}$ fue grabada al final de la línea siguiente.

Conimbriga, 55 (2016) 269-287 
siglo II, entre cuyos miembros había personas que no disfrutaban de la ciudadanía romana.

Además de cómo murió llama la atención la juventud de Prima Florentia, arrojada al Tíber por Orfeus cuando contaba tan solo dieciséis años de edad. La infancia era muy breve para las niñas romanas, quienes se prometían en torno a los siete años y a partir de los diez, aproximadamente, eran considerabas preparadas para afrontar la vida conyugal. ${ }^{6}$ De hecho, la ley estipulaba que la menor de doce años que convivía en casa del marido se hacía su mujer legítima cuando alcanzaba dicha edad, pasando entonces a estar en poder del esposo (Dig. 23. 2. 4, Pomp. 3 Sab.). La convivencia desde la niñez y una boda a edad temprana podían ayudar a salvaguardar el preciado bien de la virginidad, una inversión de futuro para la conversión de la virgen en madre. $^{7}$

\section{El castigo para los homicidas}

Desconocemos si fueron emprendidas acciones legales para perseguir a los hombres señalados en estos epitafios como culpables de los homicidios. De ser así, el proceso fue instruido por altos magistrados distintos puesto que los crímenes tuvieron dos escenarios muy diferentes: Vrbs Roma y la capital de una provincia del Imperio.

${ }^{6}$ Cantarella (1991 15). El problema que plantea cualquier estudio sobre la edad de matrimonio en la antigua Roma es, ante todo, metodológico. Son de referencia obligada los trabajos de SALLER (1987 21-34) y SHAw (1987 30-46). Se centran en época imperial y, sin renunciar a las fuentes literarias, utilizan fundamentalmente los epitafios dedicados por los cónyuges de los difuntos como indicadores de la edad de matrimonio, que defienden hay que retrasar. El estudio más reciente sobre esta cuestión es el de Lelis, Percy y Verstraete (2004 14), quienes critican la metodología estadística y privilegian las fuentes literarias de época republicana y del principado de Augusto. Los autores sostienen que los matrimonios más tempranos se producían en la prepubertad de las niñas, entre los doce y los dieciséis años, y entre los diecisiete a los veinte en el caso de los maridos.

${ }^{7}$ Incluso los ciclos vitales de las mujeres romanas estaban determinados por su aptitud física para parir. Durante la etapa de la virginidad debían prepararse para la maternidad, reservando todas sus fuerzas para cuando entraran en el de la fecundidad legalizada por el matrimonio, al que seguía el de la infertilidad, MARTínEz LóPEz (1994 169-184).

Conimbriga, 55 (2016) 269-287 
Durante el siglo II Prima Florentia fue arrojada al Tíber por su marido, quien debió ser acusado ante un jurado, tal como estaba previsto para todo crimen configurado por las leges iudiciorum publicorum. ${ }^{8}$ Si el crimen aconteció en un momento avanzado de dicha centuria, el praefectus Urbi fue el encargado de instruir el proceso, promovido ante la quaestio de sicarii et ueneficiis. Entre finales del siglo II y principios del III, el Prefecto de la Vrbs acabó teniendo competencia judicial en todo delito cometido en Roma y en el radio de cien millas de la ciudad (Dig. 1. 12. 1, Ulp., de off. praef. urb.).

La jurisdicción del crimen de Iulia Maiana, cometido entre mediados del siglo II y las primeras décadas del III, correspondió al gobernador de la Galia Lugdunense. Durante el Principado, las prerrogativas judiciales de los gobernadores fueron aumentando hasta que asumieron la persecución y juicio de todo tipo de delitos. ${ }^{9}$ El fundamento jurídico de esta ampliación de competencias fue el procedimiento extra ordinem que otorgaba al magistrado o promagistrado un poder discrecional, en virtud del cual podía tomar la iniciativa de arrestar al criminal y decidir la pena. Esta jurisdicción integral era indisociable de su exclusivo imperium merum, del cual emanaba, según Ulpiano, el ius gladii (FourNIER 2014 182, 195). Así, a comienzos del siglo III los gobernadores provinciales ya habían recibido la jurisdicción capital y la potestad de condenar a los ciudadanos romanos a trabajos forzosos en las minas (Dig. 1.12.1, de off. praef. urb.; Dig. 1.18.13, Ulp. 7 de off. proc.).

El castigo para el crimen cometido por los esposos de estas mujeres estaba determinado por dos leyes promulgadas en época tardo-republicana, todavía vigentes cuando ellas murieron.

Entre los años 50 y 55 a.C. matar a un pariente fue tipificado como delito de parricidium en virtud de la lex Pompeia de parricidis (Dig. 48. 9.1, Marc. Inst. lib.). Con ella el parricidio acabó extendiéndose progresivamente a un número cada vez mayor de parientes y

\footnotetext{
${ }^{8}$ Las cuestiones de procedimiento judicial son tangenciales aquí. La información sobre ellas desgranada en estas páginas se ha tomado de las dos obras de referencia sobre derecho penal romano: el magnífico trabajo de Mommsen (1999 I 197-228) y el muy clarificador de SANTALUCIA (1990 70-121).

${ }^{9}$ Sobre el papel del gobernador en materia judicial, FourniER (2014 171-208), HURLET (2010 231-253) y BÉRENGER (2014).
} 
adfines,${ }^{10}$ en línea directa o colateral hasta el sexto grado de parentesco.

La pena era la que la lex Cornelia de sicariis y ueneficis (año 81 a.C.) preveía para el homicidio simple. ${ }^{11}$ La opinión mayoritaria sostiene que se trataba de la interdictio aquae et ignis, en realidad una alternativa a la muerte para el homicida, a quien se daba la posibilidad de salvar la vida con un exilio voluntario. Consistía en la prohibición bajo pena de muerte de establecer el domicilio en el territorio de la ciudadanía romana o dentro de un determinado radio a partir de las fronteras italianas fijado por ley (REvière 2008 47-113).

La interdictio fue progresivamente sustituida por la deportación, que imponía un domicilio coactivo perpetuo, normalmente en una isla o en un oasis (López Huguet 2008 26, 45-48 nota 128). Así acontecía en tiempos de Marciano, quien escribe que entonces la ley Cornelia se aplicaba a quien mataba a la esposa (Dig. 48. 9. 1, Marc. 14 inst. $)^{12}$ y el homicida era deportado a una isla, con privación de todos sus bienes (Dig. 48.8.3.5, Marc. Inst. lib. 14).

Sin embargo, a partir del último tercio del siglo II ciertas circunstancias podían modificar el castigo: la condición social del homicida y el adulterio de la víctima. ${ }^{13}$ El propio Marciano precisa que la depor-

${ }^{10}$ GARCÍA GARRIDO (1990, p. 23, s.v. adfines): personas ligadas por el parentesco de afinidad que se da entre los parientes del marido y de la mujer (suegro, suegra, yerno, nuera, madrastra, padrastro, hijastros e hijastras). La causa de contraer afinidad es el matrimonio.

${ }^{11}$ Con excepción del atentado contra la vida del propio padre que era castigado con la poena cullei. Se consideraba un acto de naturaleza distinta al homicidio, un crimen que debía ser perseguido por la ciudad puesto que alteraba los fundamentos esenciales del orden jurídico romano (Thomas 1981 679-695). Sobre la poena cullei véase CANTARella (1996 245-265), quien la define como una procuratio prodigi destinada a eliminar a un monstruo más que a castigar a un reo y NúÑEZ PAZ (2010 89-103), quien trata sobre el fundamento religioso del castigo impuesto al parricida y la supuesta supresión y posterior recuperación en la lex Pompeia.

${ }^{12}$ En un fragmento de las Institutiones de Marciano la esposa aparece mencionada entre los adfines. Algunos autores defienden que su integración en la sententia legis es una interpolación de época tardía. Véase el debate historiográfico sobre esta cuestión en Thomas (1981 648-659).

${ }^{13}$ No hay duda de que Iulia Maiana y Prima Florentia no murieron por haber cometido adulterio. De haber sido así nunca sus parientes habrían denunciado públicamente los crímenes ni se habrían puesto de su lado, PAVÓn TORREJón (2011 261).

Conimbriga, 55 (2016) 269-287 
tación estaba reservada a los honestiores mientras que los humilliores debían morir por exposición a las fieras (Dig. 48. 8. 3. 5, Marc. 14 inst.; Dig. 48. 8. 16, Mod. 3 de poen.) o crucifixión (Pauli Sententiae, 5.23.1). Bajo Antonino Pío, se consideraba como atenuante para castigar a quien no negaba haber matado a su mujer si la había sorprendido cometiendo adulterio. Como resultaba difícil contener el justo arrebato y se debía castigar por el exceso más que por el deseo de venganza, los honestiores eran condenados al exilio temporal mientras que los humilliores debían exiliarse a perpetuidad (Dig. 48. 5. 39 .8, Pap. 36 quaest.).

Por su parte, Marco Aurelio y Cómodo dieron un rescripto en el que se contemplaba que si el marido mataba a su mujer sorprendida en adulterio, no sufriera la pena que la lex Cornelia establecía para los casos de homicidio (Dig. 48. 5. 39 .8, Pap. 36 quaest.).

A tenor de lo expuesto, no podemos determinar cuál fue el castigo para el esposo de Prima Florentia puesto que su epitafio fue grabado durante el siglo II, sin que se pueda precisar más. Por lo que respecta al marido de Iulia Maiana, si fue declarado culpable tuvo que haber sido condenado con la deportatio.

\section{El proceso judicial como instrumento de la venganza}

Haciendo gala de una gran erudición, Eva Cantarella reúne una serie de textos literarios, jurídicos y filosóficos que muestran cómo en la antigua Roma existió una cultura y práctica de la venganza cuyas raíces históricas son difíciles de rastrear. ${ }^{14} \mathrm{La}$ venganza siempre fue vista

${ }^{14}$ Un amplio sector de la doctrina sostiene que se remonta a la Roma de los reyes, al interpretar la conocida ley que Festo atribuye a Numa (Festo s.v. parrici. 247. 22-24 L) como una autorización dada a los familiares de la víctima de un homicidio voluntario para vengar su muerte. Véanse las distintas tesis en MommSEN (1999 III 285-290), CANTARella (1996 299-300) y NúÑEz PAz (2010 90-93), quien plantea que paricidas puede derivar de patria facere ("sanción equivalente") y que la pena sería la que procede de la aplicación de la ley del Talión. Por su parte, Bernardo Santalucia va más allá al defender que la ley de Numa no sólo permitía sino que imponía a los parientes el deber de acabar con la vida del culpable (SANTALUCia 1990 31-32), opinión que comparte Bотта (2013 8-12). En contra, Yan Thomas (Тномаs 1981 643-715; 1995 167-187), para quien el término paricidas remite al de parricidium o atentado contra la vida de un pater, no sabemos si del genitor o del paterfamilias.

Conimbriga, 55 (2016) 269-287 
como un gesto de nobleza y representaba uno de los instrumentos más poderosos de reglamentación de las relaciones sociales. ${ }^{15}$

Los familiares de la víctima de un homicidio tenían la obligación moral de vengar su muerte, deber que progresivamente fue siendo controlado judicialmente por el Estado. Resulta ilustrativo traer a colación el Primer Edicto de Cirene (VISSCHER 1940 89-103) con el que Augusto introdujo los tribunales criminales autónomos y permanentes en una provincia. Dicho comportamiento social llega a tener reconocimiento jurídico puesto que el edicto preveía que la población helena también emprendería acciones legales presentando acusación ante una quaestio perpetua porque "por regla general los parientes de las víctimas no deben dejar las muertes sin venganza".

La venganza no se ejecutaba con la obtención de la pena sino con la pretensión a la misma, es decir, promoviendo el proceso judicial (KunKel 1962 121-123; CANTARELla 1996 289). Hacerlo correspondía a los parientes de la víctima porque el homicidio consideraba de un pariente próximo se un asunto privado, incluso con posterioridad a la promulgación de la lex Pompeia. Era la solidaridad entre los allegados la que les llevaba a emprender acciones legales como gesto de venganza, de manera que la acusación criminal pública difícilmente servía como elemento de pacificación para resolver tensiones y conflictos (HUMBERT 1994 79).

Estudiando los contados procesos judiciales que las fuentes literarias nos dan a conocer, el jurista Yan Thomas comprobó que la persecución judicial del homicidio, excepción hecha del parricidio, efectivamente movilizaba a la parentela próxima de la persona fallecida y, de no haberla, a sus amigos o huéspedes. Cuando se trataba de crímenes de sangre - como los denunciados en estos epitafios - era norma que fueran los parientes masculinos de la víctima quienes presentaran la acusación (1981 696-699).

Llama poderosamente la atención que también hayan sido los parientes masculinos de Iulia Maiana y de Prima Florentia los dedicantes de estos particulares epitafios, es decir, quienes acusaron públicamente a los maridos del homicidio de ambas mujeres.

\footnotetext{
${ }^{15}$ Sobre la venganza en el mundo romano, véanse entre otros: CANTARELLA (1996 287-291), Thомаs (1984 65-100) y Bотта (2013 1-23). Más concretamente sobre la terminología relacionada con ella, MiLANi (1997 12-14) y ThOMAs (1984 63, 92, nota $38)$.
}

Conimbriga, 55 (2016) 269-287 
No parece que esta coincidencia sea una mera casualidad por las siguientes razones:

1 - Los epitafios analizados son monumentos funerarios excepcionales en el conjunto de la epigrafía latina y ambos contienen la denuncia de un crimen cometido precisamente en el seno de una familia.

2 - Los dedicantes son parientes de sangre de las difuntas, lo que cobra especial importancia teniendo en cuenta que también eran los hombres emparentados con la víctima quienes acudían a la justicia para promover la acusación del homicida.

Nótese cómo en ambos epitafios los dedicantes no son los que esperaríamos.

Sabemos que Iulia Maiana dejó dos hijos, un chico de dieciocho años y una chica de diecinueve. Lo normal es que ambos conmemoren conjuntamente a su madre $\mathrm{y}$, sin embargo, el ara fue puesta y dedicada por el hijo - pero no por su hermana - y por su tío materno, es decir, por otro hombre también unido por lazos de sangre a la difunta.

Del mismo modo, resulta llamativa la intervención de December en el epitafio de Prima Florentia. Tratándose de una persona tan joven, lo lógico es que fueran sus padres quienes dedicaran el epitafio. Así lo hicieron (fecerunt) pero a continuación se señaló que un pariente de la difunta, precisamente un pariente de sangre (cognatus),${ }^{16}$ encargó y costeó la sepultura (posuit).

Las muertes de estas mujeres a manos de sus esposos fueron consideradas actos de violencia privada, una afrenta al afecto, al honor y al interés familiar. Solo así se explica que, al igual que ocurría en el ámbito judicial, se dejara en manos de los hombres unidos por una relación de consanguinidad con las difuntas acusar públicamente a la persona que les había despojado del ser querido. Los parientes masculinos no sólo se sienten y están legitimados para emprender acciones legales, sino también para señalar públicamente a los culpables ante sus conciudadanos.

Estos monumentos funerarios fueron grabados entre los siglos II y comienzos del III y están reflejando la mentalidad de dos familias no

${ }^{16}$ GARcía GARrido (1990 32, 69, s.v. agnatus / agnati y cognatio / cognati): la cognatio es el parentesco natural que supone la filiación a los vínculos de sangre, en oposición a la adgnatio o parentesco civil cuyo fundamento es la autoridad del paterfamilias.

Conimbriga, 55 (2016) 269-287 
pertenecientes a la élite de la capital imperial. ${ }^{17}$ Todavía entonces el homicidio de un pariente próximo se entendía como un asunto de familia y se actuaba en consecuencia.

Paradójicamente, aunque funcionaba un código ético que imponía la obligación de vengar la muerte de un pariente, ese mismo código prohibía acusar a otro familiar si era culpable de haberla ocasionado. Los conceptos morales de pietas y fides ${ }^{18}$ determinaban comportamientos judiciales contradictorios. Desde una perspectiva sociológica, ambos generaban actitudes diametralmente opuestas: la imposibilidad de acudir a la justicia para acusar a un allegado y la obligación de vengarse por vía judicial, especialmente cuando había un deber hereditario de hacerlo. ${ }^{19}$

La cohesión familiar y los deberes de respeto son escrupulosamente en los crímenes de familia porque hay reticencia a debatir y cumplidos exponer las disensiones internas, lo que puede conducir a inhibirse de acudir a la justicia. Como públicamente incluso Yan Thomas (1981 $698,703)$, las normas éticas se anulan para paralizar, o al menos para convertir en difícil, toda persecución por vía judicial.

${ }^{17}$ Las fuentes literarias ofrecen una visión polarizada en la Vrbs y en el medio aristocrático. Únicamente nos informan sobre dos procesos judiciales en los que los homicidas fueron hombres -ambos altos magistrados- que mataron a sus esposas. Fueron promovidos por los padres de las interfectas, quienes recurrieron al procedimiento extraordinario de justicia criminal (cognitio extra ordinem), según el cual todo asunto era confiado al princeps o a un delegado suyo, Santalucia (1990 104-107). Tiberio, una vez encontró indicios de culpabilidad, avocó al Senado el conocimiento del crimen cometido por Plaucio Silvano (Tac. Ann. 4. 22), quedando así al margen la quaestio de sicarii et ueneficiis que atendía los casos de homicidio. La denuncia contra el tribuno de la plebe Octavio Sagita (Tac. Ann. 4. 22) fue presentada por su suegro directamente ante el Senado, órgano de represión criminal presidido por los cónsules. Estos episodios no reflejan la realidad del común de los mortales ante circunstancias similares.

${ }^{18}$ Nótese cómo los parientes de Iulia Maiana los imprecaron expresamente. De acuerdo con SALLER (1988 393-410), la pietas permite comprender mejor la estructura familiar romana que el concepto jurídico de potestas. En tanto que representa la devoción a la domus y a su paterfamilias, se presenta como centro primario de identidad y de responsabilidad social.

${ }^{19}$ Por parte de los descendientes del difunto que, si no pueden hacerlo, trasladan la obligación a sus agnados y libertos. La renuncia al proceso se aprecia tanto en el ámbito civil como criminal. Se trata de una moral que las fuentes literarias, por ejemplo Cicerón, documentan en el medio aristocrático pero que sin duda existía en el resto de la sociedad Humbert $(1994$ 77, 80).

Conimbriga, 55 (2016) 269-287 
Resulta sugerente plantear como hipótesis que este puede haber sido el motivo que explica la grabación de estos poco comunes epitafios. Las familias agraviadas pudieron buscar una venganza que no iban a obtener ante los órganos de justicia, al estar el homicida también emparentado con las víctimas. Independientemente de que así fuera, el epitafio-denuncia sirve a la parentela para ejecutar una venganza alternativa o complementaria del proceso judicial: la reprobación social del culpable.

\section{BIBLIOGRAFÍA}

Astolfi, Ricardo (2002): Il matrimonio nel diritto romano classico, Padua.

BÉRENGER, Agnès (2014): Le métier de gouverneur dans l'empire romain, París.

BоттA, Fabio (2013): "El deber de venganza en la Roma antigua" Revista General de Derecho Romano 21 1-23.

CAG, 10 = Denajar, Lauren (2005): Carte archéologique de la Gaule. 10: L'Aube, París.

Cantarella, Eva (1991): La mujer romana, Santiago de Compostela.

Cantarella, Eva (1996): Los suplicios capitales en Grecia y Roma. Orígenes y funciones de la pena de muerte en la Antigüedad clásica (trad. I supplizi capitali in Grecia e Roma, Milano, 1989), Madrid.

Castresana, Amelia (1993): Catálogo de virtudes femeninas, Madrid.

Cenerini, Francesca (2002): La donna romana: Modelli e realtà, Bolonia.

Chioffi, Laura (2015): "Death and Burial", en Jonathan Edmondson y Christer Bruun (eds.), The Oxford Handbook of Roman Epigraphy, Oxford, 627-648.

Cid López, Rosa Ma (2002): "La maternidad y la figura de la madre en la Roma antigua”, en Ana Isabel Blanco García (coord.), Nuevas visiones de la maternidad, León, 11-50.

Cid LóPez, Rosa Ma (2009): "Madres para Roma: Las castas matronas y la res publica", en Rosa $\mathrm{M}^{\mathrm{a}}$ Cid López (coord.), Madres y maternidades: Construcciones culturales en la civilización clásica, Oviedo, 155-182.

DonATI, Angela y SusInI, Giancarlo (1986): "La scrittura esposta: i modi della scrittura romana", en Gabriel Cardona (ed.), Sulle tracce della scrittura: Oggeti, testi, superfici dai musei dell'Emilia-Romagna, Bolonia, 65-78.

ENCARNAÇÃo, José d' (2008): "Leite de Vasconcelos e as inscrições romanas - flagrantes de um quotidiano vivido" $A P$ série IV 26 385-406.

FourNIER, Lauren (2014): "L'administration de la justice dans le monde romain. Ier siècle av. J.-C.-Ier siècle ap. J.-C.”, en Nicolas Mathieu (dir.), Le monde romain de 70 av. J.-C. à 73 apr. J.-C. Voir, dire, lire l'empire, París, 171-208.

García Garrido, Manuel Jesús (1990): Diccionario de jurisprudencia romana, Madrid.

Conimbriga, 55 (2016) 269-287 
Green, Miranda (1995): Mitos celtas, Madrid.

Helttula, Anne (dir.) (2007): Le iscrizioni sepolcrali latine nell'Isola Sacra, Roma.

Humbert, Michel (1994): "Le procès romain: Approche sociologique" Archives de Philosophie du Droit 39 73-86.

HuRLET, Fréderic (2010): “Tra giurisdizione cittadina e giurisdizione imperiale: La sfera di competenza del proconsule" Studi classici e orientali 56 231-253.

KUNKEL, Wolfgang (1962): Untersuchungen zur Entwicklung des römischen Kriminalverfahrens in vorsullanischer Zeit, Munich.

Lelis, Arnold A., Percy, William A. y Verstraete, Beert C. (2004): The Age of Marriage in Ancient Rome, Lewiston-Queenston-Lampeter.

López Huguet, Ma Luisa (2008): “Un análisis de los efectos jurídicos del exilium y la interdictio aquae et ignis desde sus orígenes hasta la época imperial con especial referencia a su incidencia sobre la libertad domiciliaria" Revista General de Derecho Romano 10 1-49.

Martínez López, Cándida (1994): "La virginidad de las jóvenes en la antigua Roma" Arenal 1(2) 169-184.

MARTínez LóPez, Cándida (1999): "Y parirás hijos para gloria de Roma. Las mujeres y la ciudadanía en la Roma antigua”, en Margarita Ortega, Cristina Sánchez y Celia Valiente (eds.), Género y ciudadania: Revisiones desde el ámbito privado: XII Jornadas de Investigación Interdisciplinaria, Madrid, 143-162.

Milani, Celestina (1997): "Il lessico de la vendetta del perdono nel mondo classico", en Marta Sordi (ed.), Amnistia, perdono e vendetta nel mondo antico, Milán, 3-18.

Mócsy, András y LóRINCZ, Barnabas (eds.) (1999-2002): Onomasticon prouinciarum Europae latinarum (OPEL), Viena.

Mommsen, Theodor (1999): El derecho penal romano (reimp. facsimil: Mommsen, Theodor; Dorado Montero, Pedro (trad.), Derecho penal romano, Madrid, 1905, 2 vols), Pamplona.

NúÑEZ PAZ, Ma Isabel (2010): "La no aplicación efectiva de la pena de muerte al parricida por razones religiosas. Una reflexión histórica sobre la larga pervivencia del parricidio en el derecho penal como delito autónomo" Revista Penal 25 89-103.

PAVÓn ToRrejón, Pilar (2011): "El uxoricidio de Iulia Maiana, manu mariti interfecta (CIL XIII, 2182)" Habis 42 253-262.

Raepsaet-Charlier, Marie-Thérese (2003): "Nouveaux cultores de Nehalennia" AC 72 291-302.

RÉviLle, Albert (1873-75): "Un autel de Nehalennia trouvé près de Domburg (Zélande)" Revue Celtique 2 18-20.

RIvièRe, Yann (2008): “L' interdictio aqua et igni et la deportatio sous le Haut-Empire romain (Étude juridique et lexicale)", en Philippe Blaudeau (éd.), Exil et relégation. Les tribulations du sage et du saint durant l'Antiquité romaine et chrétienne

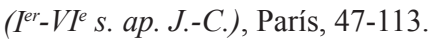

SALler, Richard P. (1987): "Men's Age at Marriage and its Consequences in the Roman Family" CP 82 21-34.

Conimbriga, 55 (2016) 269-287 
SALLER, Richard P. (1988): “Pietas, Obligation and Authority in the Roman Family”, en Peter Kneissl y Volker Losemann (eds.), Alte Geschichte und Wissenschaftsgeschichte: Festschrift für Karl Christ zum 65. Geburtstag 1 393-410.

Santalucia, Bernardo (1990): Derecho penal romano (trad. Diritto e processo penale nell'antica Roma, Milano, 1989), Madrid.

SHAw, Brent D. (1987): “The Age of Roman at Marriage: Some reconsiderations" JRS 77 30-46.

Solin, Heikki (1987): "Analecta Epigraphica, XVIII: Zu Ostiensischen Inschriften" Arctos. Acta Philo. Fennica 21 119-126.

Stuart, Petrus J. y Bogaer, Julianus E. (2001): Nehalennia. Römische Steindenkmäler aus der Oosterschelde bei Colijnsplaat, 2 vols., Leiden.

Thомаs, Yan (1981): "Parricidium. I: Le père, la famille et la cité (la lex Pompeia et le systeme des poursuites publiques)" Mélanges de l'École française de Rome. Antiquité 93 (2) 643-715.

Thомаs, Yan (1984): "Se venger au forum: Solidarités traditionnelles et système pénal à Rome", en Raymond Verdier y Jean-Pierre Poly, (eds.), Vengeance, pouvoirs et idéologies dans quelques civilisations de l'Antiquité, París, 65-100.

Thylander, Hilding (1952): Inscriptions du port d'Ostie. Vol. I: Texte; Vol. II: Planches, Lund.

Treggiari, Susan (1991): Roman Marriage: Iusti coniuges from the time of Ciceron to the time of Ulpian, Oxford.

Visscher, Fernand de (1940): Les Édits d'August découverts à Cyrène, Louvain-la-Neuve. 

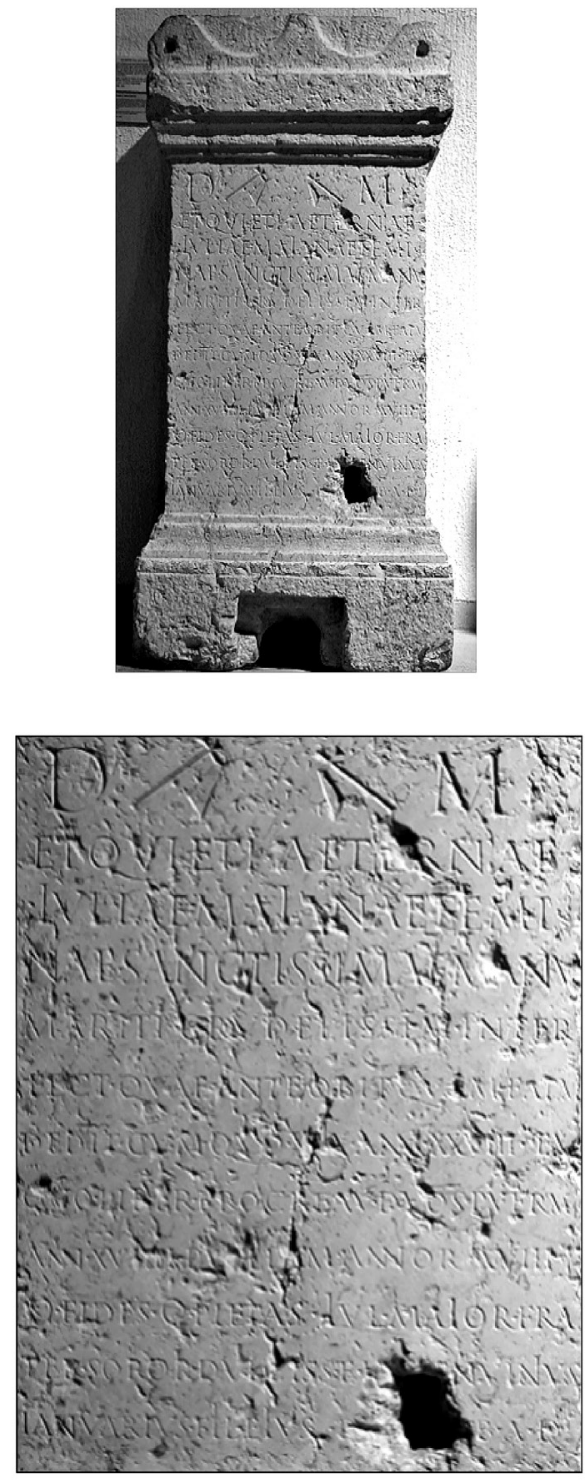

FIG. 1 


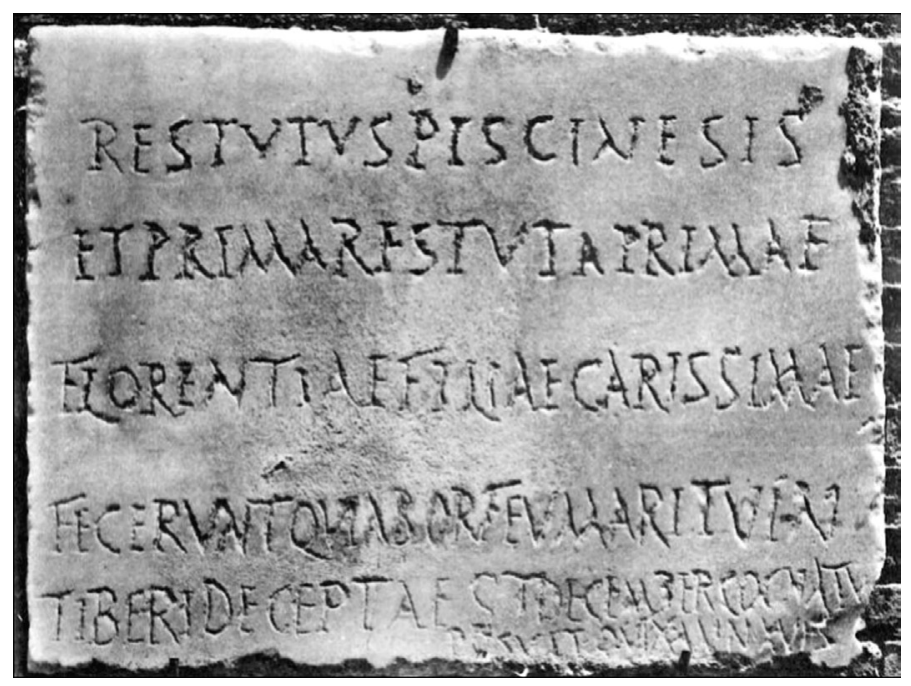

FIG. 2 